Diabetologia $5,61-66(1969)$

\title{
ORIGINALS
}

\section{Insulin Release by Isolated Pancreatic Islets of the Mouse Incubated in vitro}

\author{
E. Colu-Garota and J.R. GruL \\ Department of Biochemistry, University of Bristol \\ Received: May 24, 1968
}

\begin{abstract}
Summary. The release of insulin during ineubation of mouse islets of Langerhans, isolated after digestion of the pancreas with collagenase, has been studied, and the influence of various factors on the rate of release investigated. Glucose at $3.0 \mathrm{mg} / \mathrm{ml}$ (high glucose) stimulated insulin release, but had no effect at $0.6 \mathrm{mg} / \mathrm{ml}$ (low glucose). Mannoheptulose blocked the stimulation by high glucose, as did adrenaline. The adrenaline effect was abolished by phentolamine, an alpha-adrenergic blocking agent. Glucagon alone, stimulated insulin release, and also with low glucose, but not consistently with high glucose. Adrenaline abolished the stimulation by glucagon. Theophylline stimulated release with low glucose, much less so with high glucose and not at all with glucagon at either glucose concentration. Tolbutamide stimulated release with low glueose, and this effect was not inhibited by adrenaline. The suitability of this preparation for studies of islet cell metabolism and its relationship to secretion of insulin is discussed.
\end{abstract}

Libération de l'insuline par les ôlots paneréatiques isolés de la souris, incubés "in vitro"

Résumé. La libération de l'insuline pendant l'incu. bation des îlots de Langerhans de la souris, isolés après digestion du pancréas par la collagénase, a ététudiée, et l'influence de divers facteurs sur la vitesse de libération a été recherchée. Le glucose à $3.0 \mathrm{mg} / \mathrm{ml}$ (glucose élevé) stimulait la libération d'insuline, mais n'avait pas d'effet à $0.6 \mathrm{mg} / \mathrm{ml}$ (taux bas). Le mannoheptulose bloquait la stimulation provoquée par du glucose élevé, comme le faisait l'adrénaline. L'effet de l'adrénaline était aboli par la phentolamine, un agent bloquant alpha adrénergique. Le glueagon seul, ainsi qu'en pre'sence d'un taux de glu. cose bas, stimulait la libération d'insuline, mais non de façon constante avec un taux de glucose élevé. L'adrénaline abolissait la stimulation provoquée par le glucagon. La théophylline stimulait la libération lorsque le glucose était bas, mais beancoup moins lorsque le glucose était élevé et pas du tout avec le glucagon, quelle que soit la concentration de glucose. Le tolbutamide stimulait la libération d'insuline avec une faible concentration de glucose et cet effet n'était pas inhibé par l'adrénaline. La convenance de cotte préparation pour des études sur le métabolisme des cellules insulaires et sa relation avoc la sécrét ion d'insuline est discutée.

Insulin-Freisetzung aus isolierten und in vitro inkubierten Pankreasinseln von Mäusen

Zusammenfassung. Es wurde die Insulinausschüttung aus Langerhans'schen Inseln von Mäusen, die durch Kollagenase-Behandlung des Pankreas gowonnen worden waren, untersueht und der EinfluB verschiedener Faktoren auf die Freisetzungsgeschwindigkeit überprüfft. Eine hohe Glucose-Konzentration von $3.0 \mathrm{mg} / \mathrm{ml}$ förderte die Insulin-Ausschüttung, während die niedrige Konzentration von $0.6 \mathrm{mg} / \mathrm{ml}$ keine Wirkung ergab. Mannoheptulose und Adrenalin blockierten die Stimulation durch die hohe Glucosekonzentration. Der Adrenalin. Effekt konnte durch Phentolamin, eine alpha-Rezeptoren blockierende Substanz, wieder aufgehoben werden. Glucam gon führte allein und in Gegenwart der niedrigen Glucose. konzentration zu einer verstärkten Insulininkretion: dies war jedoch bei Kombination mit der hohen Glueosekonzentration nicht lsonstant der Fall. Adrenalin hob dio Stimulierung durch Glucagon auf. Theophyllin führte bei Gegenwart der niedrigen Glucosekonzentration zu einer gesteigerten Ausschüttung, dieser Effekt trat unter der höheren. Glucosekonzentration in wesentlich geringerem Umfang und bei Zusatz von Glucagon und einer der beiden verwandten Glucosekonzentrationen überhaupt nicht auf. Bei niedriger Glucosekonzentration stimulierte Tolbutamid die Insulinfreisetzung; dieser Effekt ließ sich durch Adrenalin nicht aufheben. Die Aussagefähigkeit dieses Präparates für Untersuchungon des Inselzell-Stoffweehsels und seiner Beziehungen zur Insulininkretion wird diskutiert.

Key-words: Insulin, islots of Langerhans, mouse, collagenase, glucose, mannoheptulose, glucagon, adrenaline, phentolamine, theopbylline, tolbutamide.
Different procedures have been used to study in vitro the factors which regulate insulin secretion. These investigations were initiated by AxDERSon and LoNG (1947) by means of the perfused rat pancreas, a preparation that has been extensively used following the development of insulin radioimmunoassay (e.g. see Grodsky et al., 1967). Coore and RaNdif (1964) have described a system for studies in vitro of the control of insulin secretion which is based on the rate of release of the hormone into the incubation medium from pieces of rabbit pancreas.

Although these preparations have proved useful for a study of the factors which may control insulin release, they are of limited value for studying the relationships between islet cell metabolism and release, on account of the large excess of acinar tissue. RecentIy, two preparations have been developed which may be suitable for metabolic studies. These are pancreatic islets isolated from mouse pancreas by micro-dissection (HELlfirström, 1964), or from rat pancreas by mioro-dissection (JARRETT and KEEN, 1966) or collagenase digestion (LAOY and KOSTIANOVsky, 1967), and $\beta$ cells obtained by organ culture of foetal rat pancreas (VECCHO, LUYCKX, ZAHND and RENOLD, 1966).

In the present study, the influence of various factors on insulin release by mouse pancreatic islets isolated with a collagenase method is described. The reproducibility of response suggests that the preparation may be suitable for a study of the metabolic events which lead to the release of insulin. 


\section{Materials and Methods}

Mice. The pancreatic islets were obtained from male albino mice (Tucks No. 1, Bristol, England) of about eight weeks of age and weighing $25-30 \mathrm{~g}$. The animals were fed ad libitum with Diet $41 \mathrm{~B}$, "Oxoid" Division (Oxo Ltd., London, England), and had free access to drinking water.

Chemicals. D-Mannoheptulose was given by Professor E. Simon (Rehovoth, Israel), and crystalline glueagon was a gift of Eli Lilly \& Co. (Indianapolis, U.S.A.; Lot 258-234B-167-1). Bovine plasma albumin was Fraction $V$ from the Armour Pharmaceutical Co. Ltd. (Eastbourne, Sussex). Collagenase was obtained from Sigma Chemical Co. (St. Louis, Missouri, U.S.A.; Practical Grade Type II, from Cl. histolyticum, Lot 15B-2150). Tolbutamide was obtained from Burroughs Wellcome \& Co. (Beckenham, Kent), and phentolamine ("Rogitine") from Ciba Laboratories Ltd. (Horsham, Sussex). All other chemicals were obtained from British Drug Houses Ltd (Poole, Dorset).

Mouse insulin. Used as a standard for the immunoassay, was prepared by an adaptation of the method of Davoren (1962), $60 \mathrm{~g}$ of pancreas tissue was obtained from 200 adult male mice and frozen in a mixture of acetone and solid carbon dioxide. The insulin was extracted in a total of $360 \mathrm{ml}$ of acid ethanol at $0^{\circ}$ and the extract separated by centrifugation. The residue was re-extracted with a further $160 \mathrm{ml}$ of acid ethanol. The pooled extracts were adjusted to $\mathrm{pH} 8.2-8.4$ with ammonia. The precipitate was discarded and the supernatant brought to $\mathrm{pH} 5.5$ with $\mathrm{HCl}$, and $2.0 \mathrm{ml}$ of $2.0 \mathrm{MI}$ ammonium acetate $\mathrm{pH} 5.3$ was added.

Two volumes of ethanol and four volumes of diethyl ether were added, and the mixture was maintained at $-10^{\circ}$ for $16 \mathrm{~h}$. The precipitate was collected by centrifugation at $-5^{\circ}$ and dissolved in $40 \mathrm{ml}$ of water brought to $\mathrm{pH} 2-4$ with $2 \mathrm{~N} \mathrm{HCl}$. An equal volume of $30 \%(\mathrm{w} / \mathrm{v})$ solution of sodium chloride was added, and the precipitate of crude insulin separated by centrifugation.

The insulin was dissolved in a minimum volume of M acetic acid, and transferred to a column $(120 \mathrm{~cm} \times$ $2 \mathrm{~cm}$ ) of Sephadex G50 (Pharmacia, Uppsala, Sweden) suspended in $\mathbf{M}$ acetic acid. Elution was carried out with M acetic acid and fractions of approximately $3.0 \mathrm{ml}$ were collected. Protein in the eluate was estimated by optical density at $280 \mathrm{~m} \mu$, and insulin by immunoassay of $0.1 \mathrm{ml}$ samples dried in a vacuum dessicator over $\mathrm{NaOH}$. The fractions containing the bulk of the insulin were pooled and freeze-dried.

The column was washed with four bed-volumes of M acetic acid, and the freeze-dried preparation was rechromatographed on the same column. The insulin appeared as a sharp peak of absorbing material. The three fractions forming the top of this peak were pooled, and without further purification the insulin was used as a standard for all immunoassays of mouse insulin.
The standard was stored in aliquots of $8.4 \mu \mathrm{g}$ in small glass tubes. $50 \mu \mathrm{l}$ of the solution of $4 \mathrm{mg} / \mathrm{ml}$ albumin (treated to remove insulin and free fatty acids by the method of Garland, Newsholme and RandLE, 1964) and $100 \mathrm{mg} / \mathrm{ml}$ sucrose was added to each tube, and all were dried over $\mathrm{NaOH}$ in a vacuum dessicator. The standards were stored over $\mathrm{P}_{2} \mathrm{O}_{5}$ in a dessicator at $-10^{\circ}$.

Immunoassay of insulin. The concentrations of insulin in the incubation media were determined in triplicate samples by Method $\mathrm{C}$ of $H_{\text {ALES }}$ and $\mathrm{R}_{\text {ANDLE }}$ (1963), using 125I-labelled ox-insulin obtained from The Radiochemical Centre (Amersham, Bucks.) and guinea pig anti-human-insulin serum.

\section{Procedure}

Incubation media. The medium for all incubations was a bicarbonate-buffered salt solution (KREBs and Henseleit, 1932), supplemented with the sodium salts of pyruvie, glutamic and fumaric acids at concentrations of approx. $5 \mathrm{mM}$ (KREBS, 1950), and containing bovine plasma albumin $(2 \mathrm{mg} / \mathrm{ml})$ to avoid adsorption of insulin to the glass. The gas phase was $\mathrm{O}_{2}+\mathrm{CO}_{2}(95: 5)$. Further additions to the medium are described in the text or in the Tables.

Preparation of pancreatic islets. The method of Lacy and Kostianovsky (1967) was used to isolate the islets from the mouse pancreas, with some modifications introduced by HoweLL and TAYLOR (1966) and a few others developed in the course of the present study.

Each mouse was killed by decapitation, the splenic portion of the pancreas was rapidly removed and dropped into oxygenated bicarbonate-buffered salt solution (KreBs and Henseleit, 1932) in a Petri dish over an ice bath. Usually four mice were used in each experiment. The connective tissue planes of the organ were distended by injection of cold buffer under the capsule using a syringe and a fine needle (No. 18), after which the tissue was divided into small pieces with scissors and washed twice with fresh, cold buffer. Some of the excess fat floats in this medium and can be easily removed with fine forceps. The fragments were immediately placed in a conical flask containing the collagenase solution $(15 \mathrm{mg}$ in $1.5 \mathrm{ml}$ of buffer for each pancreas), and incubated at $37^{\circ} \mathrm{C}$ for $20-30$ minutes with rapid shaking ("Mickle" Electric Shaking Incuba" tor, Gomshall, Surrey). After incubation the suspension was transferred to a conical tube, diluted to about $10 \mathrm{ml}$ with the same buffer, and centrifuged at very low speed for two minutes. The supernatant was discarded, the sediment was resuspended in fresh buffer and centrifuged again, twice in all, in order to wash the preparation and remove the collagenase. The precipitate from the last centrifugation was resuspended in supplemented incubation medium containing a low concentration of glucose $(0.6 \mathrm{mg} / \mathrm{ml})$ and transferred to a Petri dish over an ice bath. The preparation was examined under the dissection microscope (Stereo- 
scopic Microscope with Universal Stand MBC-2, U.S.S.R.), and the islets were taken into the pre-incubation flask using a thin wire loop which was about the diameter of the islets.

Incubation of the islets. The isolated islets were preincubated in lots of 60-80 in five $\mathrm{ml}$ of medium with low glucose $(0.6 \mathrm{mg} / \mathrm{ml})$ at $37^{\circ} \mathrm{C}$ for $30 \mathrm{~min}$, with shaking $(70-80$ cycles per $\min )$ in the same incubator used previously. The purpose of this preincubation was to permit fading of possible insulin release in response to the terminal hyperglycaemia of the animal (CoORe and RANDLE, 1964).

Using the same method described above, the islets were transferred after preincubation into the incubation flasks (small tubes $2 \mathrm{~cm} \times 1 \mathrm{~cm}$, fitted with rubber stoppers), five islets in $0.6 \mathrm{ml}$ of medium in each flask. Incubation was carried out for one hour under the same conditions as for the preinoubation. The media were centrifuged to pack the islets, and samples $(0.1 \mathrm{ml})$ were taken at the end for assay of insulin content. All incubation media were saturated with $\mathrm{O}_{2}+\mathrm{CO}_{2}(95: 5)$ before the preincubation and the incubation of the islets.

Calculation and expression of results. The rates of release of insulin have been caloulated and expressed in the Tables as $\mu \mu \mathrm{g}$ of insulin/min.islet. For these calculations it was assumed that the insulin preparation used as the standard was pure.

\section{Results}

Time course of insulin release. The insulin secretion during ninety minutes was observed by inoubating the islets in bicarbonate-buffered salt solution supplemented with pyruvate, glutamate and fumarate, without added glucose, and in the same medium with addition of glucose at low $(0.6 \mathrm{mg} / \mathrm{ml})$ and at high $(3.0$ $\mathrm{mg} / \mathrm{ml}$ ) concentrations. Fig. 1 shows that there was a small release of insulin in the absence of glucose, which was of about the same magnitude as that released
$137 \pm 12 \mu \mu \mathrm{g}$ of insulin/min.islet (mean \pm S.E.M.). No significant increase in release was observed with glucose at a concentration of $0.6 \mathrm{mg} / \mathrm{ml}$ (output $188 \pm 28$ $\mu \mu \mathrm{g} / \mathrm{min}$.islet), but release of insulin increased significantly to $498 \pm 41 \mu \mu \mathrm{g} / \mathrm{min}$.islet when the glucose concentration was raised to $3.0 \mathrm{mg} / \mathrm{ml}$. The effect of glueose was very consistent and reproducible, a significant inerease in output being observed in all of six different, paired experiments, using between six and twelve incubation flasks in each of them.
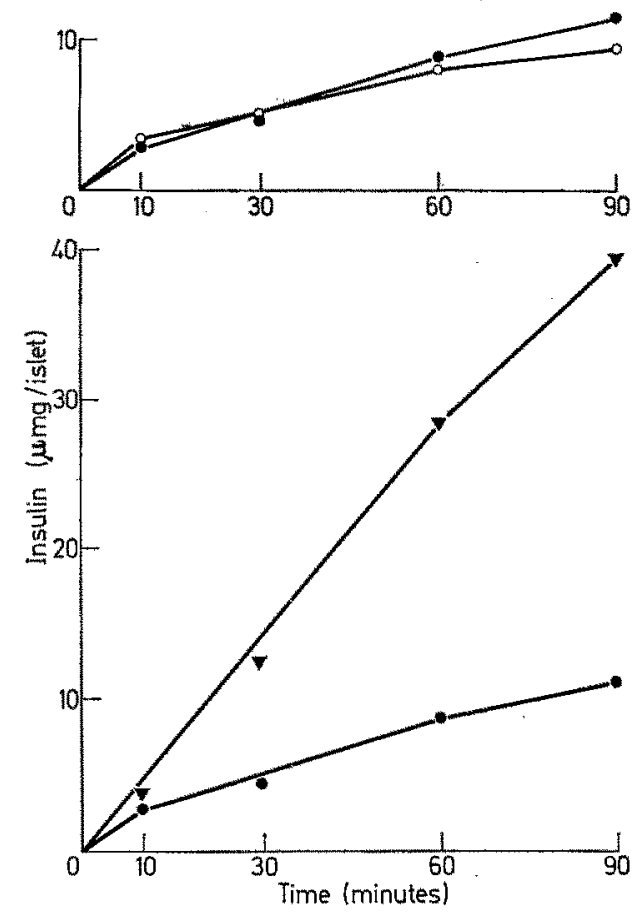

Fig. 1. Time course of insulin release. Incubation was earried out in the absence of added glucose (upper section, open cireles), in the presence of $0.6 \mathrm{mg} / \mathrm{ml}$ glucose (upper and lower sections, elosed circles) or $3.0 \mathrm{mg} / \mathrm{ml}$ glucose (lower section, olosed triangles)

Table 1. Iffect of sugars: glucose and D-monnoheptulose

\begin{tabular}{lllll}
\hline & & & Difference & Signifieance \\
\hline Glucose $(0.6 \mathrm{mg} / \mathrm{ml})$ & $72 \pm 6$ & $(6)$ & +23 & n.s. \\
Glucose $(0.6 \mathrm{mg} / \mathrm{ml})+$ & $95 \pm 4$ & $(6)$ & & \\
Mannoheptulose $(3.0 \mathrm{mg} / \mathrm{ml})$ & & & & \\
Glucose $(3.0 \mathrm{mg} / \mathrm{ml})$ & $652 \pm 59(6)$ & -475 & $p<0.01$ \\
Glucose $(3.0 \mathrm{mg} / \mathrm{mal})+$ & $177 \pm 36$ & $(6)$ & & \\
Mannoheptulose $(3.0 \mathrm{mg} / \mathrm{ml})$ & & & & \\
\hline
\end{tabular}

Results expressed in $\mu \mu g /$ min.islet (mean \pm s.e.m.)

In parenthesis number of observations.

when glucose was added in low concentration, whereas the rate of release induced by a high concentration of glucose is greater (about threefold at $60 \mathrm{~min}$ ).

Effect of sugars: glucose and D-mannoheptulose. The output of insulin by the islets incubated in twelve flasks (5 islets per flask) in the absence of glucose was
COORE and Raxpre (1964) have described the effect of D-mannoheptulose on insulin release, and the metabolic actions of that sugar on carbohydrate utilization have been reviewed by StMon and KraICER (1966). Mannoheptulose at a concentration of $3.0 \mathrm{mg} /$ $\mathrm{ml}$ had no effect on insulin release at a low concentra- 
Table 2. Elffect of hormones: glucagon and adrenaline

\begin{tabular}{|c|c|c|c|}
\hline & & Difference & Significance \\
\hline Glucose $(0.6 \mathrm{mg} / \mathrm{ml})$ & $178 \pm 27(12)$ & \multirow[b]{2}{*}{+365} & \multirow[b]{2}{*}{$p<0.01$} \\
\hline $\begin{array}{l}\text { Glucose }(0.6 \mathrm{mg} / \mathrm{ml})+ \\
\text { Glucagon }(5 \mu \mathrm{g} / \mathrm{ml})\end{array}$ & $543 \pm 86(12)$ & & \\
\hline Glucose $(3.0 \mathrm{mg} / \mathrm{ml})$ & $465 \pm 43(12)$ & \multirow{2}{*}{+148} & \multirow{2}{*}{$p<0.05$} \\
\hline $\begin{array}{l}\text { Glucose }(3.0 \mathrm{mg} / \mathrm{ml})+ \\
\text { Glucagon }(5 \mu \mathrm{g} / \mathrm{ml})\end{array}$ & $613 \div 53(12)$ & & \\
\hline Glucose $(0.6 \mathrm{mg} / \mathrm{ml})$ & $156 \pm 25(12)$ & \multirow[b]{2}{*}{+36} & \multirow[b]{2}{*}{ n.s. } \\
\hline $\begin{array}{l}\text { Glucose }(0.6 \mathrm{mg} / \mathrm{ml})+ \\
\text { Adrenaline }(200 \mu \mathrm{mg} / \mathrm{ml})\end{array}$ & $192 \pm 29(12)$ & & \\
\hline Glucose $(3.0 \mathrm{mg} / \mathrm{ml})$ & $475 \pm 43(12)$ & \multirow{2}{*}{-287} & \multirow{2}{*}{$p<0.01$} \\
\hline $\begin{array}{l}\text { Glucose }(3.0 \mathrm{mg} / \mathrm{ml})+ \\
\text { Adrenaline }(200 \mu \mathrm{mg} / \mathrm{ml})\end{array}$ & $188 \pm 22(12)$ & & \\
\hline Glucose $(3.0 \mathrm{mg} / \mathrm{ml})$ & $399 \pm 45$ & \multirow[b]{2}{*}{$-\mathbf{3 4 0}$} & \multirow[b]{2}{*}{$p<0.01$} \\
\hline $\begin{array}{l}\left.\text { Glucose }(3.0 \mathrm{mg} / \mathrm{ml})+\frac{1}{/ m}\right) \\
\text { Adrenaline }(200 \mu \mathrm{mg} / \mathrm{ml})\end{array}$ & $59 \pm 12$ & & \\
\hline $\begin{array}{l}\text { Glucose }(3.0 \mathrm{mg} / \mathrm{ml}) \\
\text { Adrenaline (id) + Phentolamine } \\
(100 \mu \mathrm{g} / \mathrm{ml})\end{array}$ & $497 \pm 85$ & +438 & $p<0.01$ \\
\hline Glucose $(0.6 \mathrm{mg} / \mathrm{ml})$ & $78 \pm 22 \quad(6)$ & \multirow{2}{*}{+270} & \multirow{2}{*}{$p<0.01$} \\
\hline $\begin{array}{l}\text { Glucose }(0.6 \mathrm{mg} / \mathrm{ml})+ \\
\text { Glucagon }(5 \mu \mathrm{g} / \mathrm{ml})\end{array}$ & $348 \pm 69$ & & \\
\hline $\begin{array}{l}\text { Glucose }(0.6 \mathrm{mg} / \mathrm{ml})+ \\
\text { Adrenaline }(200 \mu \mathrm{mg} / \mathrm{ml})\end{array}$ & $83 \pm 27 \quad(6)$ & +5 & $\begin{array}{l}\text { n.s. } \\
\text { (against } \\
\text { low gluc.) }\end{array}$ \\
\hline $\begin{array}{l}\text { Glucose }(0.6 \mathrm{mg} / \mathrm{ml})+ \\
\text { Glucagon }(5 \mu \mathrm{g} / \mathrm{ml})+ \\
\text { Adrenaline }(200 \mu \mathrm{mg} / \mathrm{ml})\end{array}$ & $93 \pm 13 \quad(6)$ & +15 & $\begin{array}{l}\text { n.s. } \\
\text { (against } \\
\text { low gluc. } \\
+ \text { adrenaline) }\end{array}$ \\
\hline & & -255 & $\begin{array}{l}p<0.01 \\
\text { (against } \\
\text { low gluc. } \\
+ \text { glucagon) }\end{array}$ \\
\hline Glucose $(3.0 \mathrm{mg} / \mathrm{ml})$ & $548=51 \quad(6)$ & -24 & n.s. \\
\hline $\begin{array}{l}\text { Glucose }(3.0 \mathrm{mg} / \mathrm{ml})+ \\
\text { Glucagon }(5 \mu \mathrm{g} / \mathrm{ml})\end{array}$ & $524 \pm 35$ & & \\
\hline $\begin{array}{l}\text { Glucose }(3.0 \mathrm{mg} / \mathrm{ml})+ \\
\text { Adrenaline }(200 \mu \mathrm{mg} / \mathrm{ml})\end{array}$ & $154 \pm 26$ & -394 & $\begin{array}{l}p<0.01 \\
\text { (against } \\
\text { high glue.) }\end{array}$ \\
\hline $\begin{array}{l}\text { Glucose }(3.0 \mathrm{mg} / \mathrm{ml})+ \\
\text { Glucagon }(5 \mu \mathrm{g} / \mathrm{ml})+ \\
\text { Adrenaline }(200 \mu \mathrm{mg} / \mathrm{ml})\end{array}$ & $131 \pm 9$ & -393 & $\begin{array}{l}p<0.01 \\
\text { (against } \\
\text { high gluc. } \\
+ \text { glucagon) }\end{array}$ \\
\hline
\end{tabular}

Results expressed in $\mu \mu \mathrm{g} / \mathrm{min}$. islet (mean $t$ s.e.m.)

In parenthesis number of observations. 
tion of glucose $(0.6 \mathrm{mg} / \mathrm{ml})$, but it suppressed the stimulating effect of glucose at $3.0 \mathrm{mg} / \mathrm{ml}$, as can be seen in Table 1.

Effect of hormones: glucagon and adrenaline. Glucagon at $5 \mu \mathrm{g} / \mathrm{ml}$ stimulated the output of insulin from the islets in the absence of glucose and in the presence of a low concentration of glucose $(0.6 \mathrm{mg} / \mathrm{ml})$. When the islets were incubated with glucose at high concentration $(3.0 \mathrm{mg} / \mathrm{ml})$ there was a barely significant increase of insulin output induced by glueagon, but in another experiment the difference was not significant. These results are given in Table 2.
The stimulating effect of glucagon was also suppressed by adrenaline $(200 \mu \mathrm{mg} / \mathrm{ml})$, both in the presence of low and high concentrations of glucose.

Effect of drugs: tolbutamide and theophylline. At low concentration of glucose $(0.6 \mathrm{mg} / \mathrm{ml})$ tolbutamide $(200 \mu \mathrm{g} / \mathrm{ml})$ stimulated insulin release. In these experiments adrenaline did not show any effect on tolbutamide action.

The effect of theophylline on insulin release was investigated because it is known that this drug may increase the intracellular concentration of cyclic $3^{\prime}$, $\overline{5}^{\prime}$-AMP by inhibiting cyclic-nucleotide phosphodieste-

Table 3. Effect of drugs: tolbutamide and theophylline

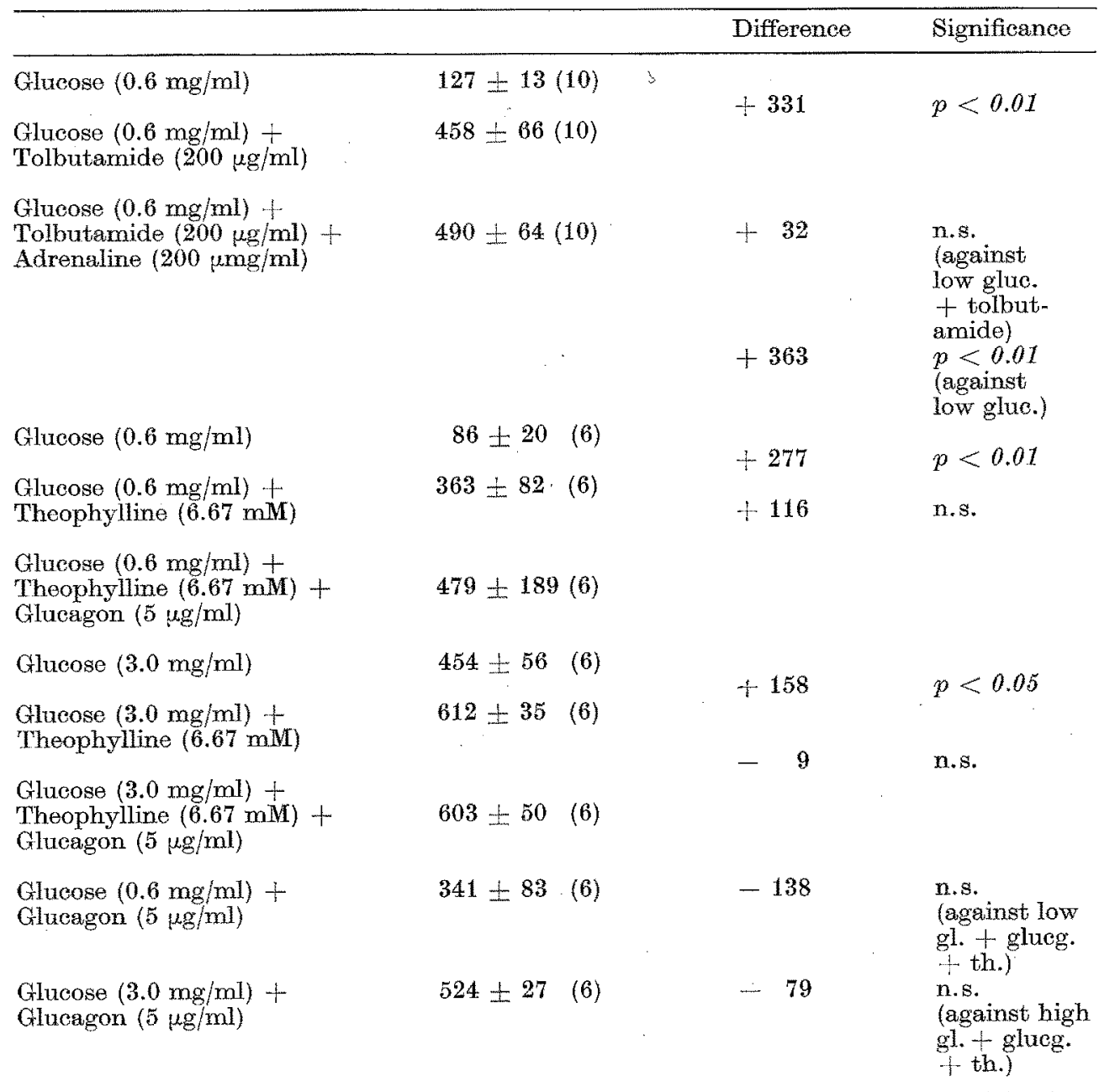

Results expressed in $\mu \mu \mathrm{g} / \mathrm{min}$. islet (mean \pm s.e.m.)

In parenthesis number of observations.

At low glucose concentration $(0.6 \mathrm{mg} / \mathrm{ml})$ adrenaline $(200 \mu \mathrm{mg} / \mathrm{ml})$ had no effect on insulin release, but it completely abolished the effect of a high concentration of glucose $(3.0 \mathrm{mg} / \mathrm{ml})$. This inhibitory effect of adrenaline was removed by phentolamine $(100 \mu \mathrm{g} / \mathrm{ml})$ (PorTw, 1967). These results are also shown in Table 2. rase (BuTCher and SUTHERLAND, 1962), and it could be that this nucleotide is involved in insulin release. TURTLE et al. (1967) have observed stimulation of insulin output induced by injection of theophylline into rats in vivo, and the same effect has been observed in vitro by GroDskx et al. (1967) using the isolated 
perfused pancreas of the rat. At low concentration of glucose $(0.6 \mathrm{mg} / \mathrm{ml})$ theophylline $(6.67 \mathrm{mM})$ stimulated insulin release markedly, but much less so in the presence of a high glucose concentration $(3.0 \mathrm{mg} / \mathrm{ml})$. Theophylline apparently does not increase the stimulation induced by glucagon at either level of glucose concentration. All these results are given in Table 3 .

\section{Discussion}

Studies of insulin release in vitro using either pieces of rabbit pancreas or perfused rat pancreas have been limited because the presence of a vast excess of acinar tissue has made these preparations unsuitable for studies of islet cell metabolism. Two questions about the control of insulin secretion prompted by such studies require investigations of the control processes in the metabolism of pancreatic islets. The release response to glucose and other sugars, and the effect of mannoheptulose, suggested that glucose metabolism through its phosphorylation to glucose 6-phosphate might be intimately connected with the release process. Secondly, the role of cyclic $3^{\prime}, 5^{\prime}$-AMP in the effects of adrenaline and glucagon was of particular interest since these hormones have opposing effects on insulin release.

The present investigations were undertaken to ascertain the suitability of mouse islets for metabolic studies. Mouse pancreas was chosen for three reasons. $\beta$-cells comprise a large fraction $(80 \%)$ of the cells present in mouse islets (HELLERSTRÖM and HELLMAN, 1963); the small size of the pancreas makes it possible to pool islets from a number of pancreases from different animals thus minimising the possibility of individual variation; and the elegant studies of HELLERSTRöM (1966), Hexuerström and HelcmaN (1963), and Herrman et al. (1964) have already provided information about the respiration and some enzymic activities of islets of this species.

The present studies have shown that mouse islets prepared by a collagenase method show many of the features of insulin release seen previously in vitro with preparations of rabbit and rat pancreas, and in vivo in man and other animals. Thus the mouse islets showed stimulation of release with glucose, glucagon, tolbutamide and theophylline; suppression of the glucose effect with mannoheptulose and adrenaline; suppression of the adrenaline effect with phentolamine; and suppression of glucagon stimulation with adrenaline. These responses suggest that mouse islets prepared by the collagenase method are a suitable preparation for metabolic studies concerned with mechanisms for the control of insulin release.

Acknowledgements: This research was supported by grants from the Medical Research Council and the British Diabetic Association to Professor P.J. RANDIA. The authors are indebted to Professor P.J. RANDLE for his interest and encouragement, and to Mrs. J.E. EABORN and Mrs. I.M. HARRIs for skilled technical assistance.

\section{References}

Anderson, E., and J.A. Long: The effect of hyperglycemia on insulin secretion as determined with the isolated rat pancreas in a perfusion apparatus. Endocrinology 40, 92-97 (1947).

Butcher, R.W., and E.W. Sutharland: Adenosine 3', $5^{\prime}$-phosphate in biological materials. J. biol. Chem. 237, $1244-1250$ (1962).

Coore, H.G., and P.J. RANDLE: Regulation of insulin secretion studied with pieces of rabbit pancreas incubated in vitro. Biochem. J. 93, 66-78 (1964).

Davoren, P.R.: The isolation of insulin from a single cat pancreas. Biochim. biophys. Acta 63, 150-153 (1962).

Garland, P.B., E.A. Newsholme, and P.J. Randle: Regulation of glucose uptake by muscle. Biochem. J.93, $665-678(1964)$

Grodsky, G.M., L.L. Bennetr, D.F. Smrth, and F.G. ScнмпD : Effect of pulse administration of glucose or glucagon on insulin secretion in vitro. Metabolism 16, $222-233$ (1967).

HALES, C.N., and P.J. RANDLE: Immunoassay of insulin with insulin-antibody precipitate. Biochem. J. $\mathbf{8 8}$, $137-146$ (1963).

Helderström, C.: A method for the microdissection of intact pancreatic islets of mammals. Acta endocr. (Kbh.) 45, 122-132 (1964).

- Oxygen consumption of isolated pancreatic islets of mice studied with the Cartesian-diver micro-gasometer. Biochem. J. 98, $7 \mathrm{C}-9 \mathrm{C}$ (1966).

-, and B. HellmaN: Quantitative studies on isolated pancreatic islets of mammals. Acta endocr. (Kbh.) 42, $615-624$ (1964).

Heltman, B., C. Helteriström, S. Westmat, H. HamMAR, and U. ROTHMAN: Preparation of pancreatic islet cells for biochemical analyses. In: The Structure and Metabolism of the Pancreatic Islets p. 193. (S.E. Brolin, B. Heluman and H. KNUTson, eds.) Oxford: Pergamon Press 1964.

HowELL, S.L., and K.W. TAYLOR: Effects of glucose concentration on incorporation of $\left.{ }^{3} \mathrm{H}\right]$ leucine into insulin using isolated mammalian islets of Langerhans. Biochim. biophys. Acta 130, 519-521 (1966).

JARRETT, R.J., and H. Krew: Glucose metabolism of isolated mammalian islets of Langerhans. Lancet $\mathbf{1 9 6 6}$ I, $633-635$.

Krebs, H. A. : Body size and tissue respiration. Biochim. biophys. Acta 4, 249-269 (1950).

-, and K. HENSELEIT: Untersuchungen über die Harnstoffbildung im Tierkörper. Hoppe-Seylers Z. physiol. Chem. 210, 33-66 (1932).

Lacy, P.E., and M. Kostianovsky: Method for the isolation of intact islets of Langerhans from the rat pancreas. Diabetes 16, 35-39 (1967).

Porte, D.Jr.: A receptor mechanism for the inhibition of insulin release by epinephrine in man. J. clin. Invest. 46, 86-94 (1967).

SIMon, E., and P.F. KraICER: The blockade of insulin secretion by mannoheptulose. Israel J. Med. Sci. 2, $785-806(1966)$.

TURTLe, J.R., G.K. LittLetor, and D.M. KiPnis: Stimulation of insulin secretion by theophylline. Nature 213, $727-728(1967)$.

VeCChto, D., A. LuYCKz, G.R. ZAhNd, and A. E. Reyold : Insulin release induced by glucagon in organ cultures of fetal rat pancreas. Metabolism 15, 577--581 (1966).

E. Colit-Garcta

Catedra de Fisiopatologia

Facultad de Modicina

Caracas, Venezuela 